\title{
THE EFFECT OF SPIN COATING SPEED AND DEPOSITION PARAMETERS ON THE CRYSTALLINE SIZE OF ZnO THIN FILMS
}

\author{
Aqeel Ali Al-Attar ${ }^{1}$, Safaa Mohammad Hasony ${ }^{2}$, Ali Hussein Ali ${ }^{3}$ \\ ${ }^{1,3}$ Assistant Lecturer, Production and Metallurgy Engineering Department \\ University of Technology, Iraq. \\ ${ }^{2}$ Assistant Lecturer, Institute of Technology-Baghdad, Iraq. \\ E-mail: akeel_attar@yahoo.com ${ }^{1}$, as_5599@yahoo.com ${ }^{2}$, ali@yahoo.com ${ }^{3}$ \\ (Received: 3/9/2012; Accepted: 29/1/2013)
}

\begin{abstract}
ZnO thin films have been deposited onto the glass-substrates by the solgel spin coating method at different chuck rotation rates. This method was used for the preparation of thin films on the important semiconductors II-VI. The effect of deposition parameters on the structural, optical and electrical properties of the $\mathrm{ZnO}$ thin film was investigated. Zinc acetate dehydrate, 2- methoxethanol and monoethanolamine (MEA) were used as a starting material, solvent and stabilizer, respectively. XRD of the dried gel showed that weight loss continued until $300^{\circ} \mathrm{C}$, with smallest particle size at $400 \mathrm{rpm}$ spin coating speed.
\end{abstract}

Keywords: ZnO, Sol-Gel Spin Coating, Crystal Structure, Optical Band Gap.

\section{INTRODUCTION}

$\mathrm{ZnO}$ thin film is one of the II-VI compound semiconductors and is composed of hexagonal crystal structure. $\mathrm{ZnO}$ thin film presents investigation in optical, acoustical and electrical properties which can be useful in applications in the fields of electronics, $(1,2)$ optoelectronics and sensors. $\mathrm{ZnO}$ thin film applied in transparent, ${ }^{(1,3)}$ conductive film, solar cell window and surface acoustic wave (SAW) device and film bulk acoustic resonator (FBAR) because of its excellent piezoelectric properties. ${ }^{(4,5)}$

The $\mathrm{ZnO}$ thin film is prepared using various methods such as spray pyrolysis, sputtering, sol-gel spin coating, pulsed laser deposition and chemical vapor deposition. ${ }^{(2,6)}$ 


\section{EXPEREMENTAL AND PROCEDURE}

$\mathrm{ZnO}$ thin films were deposited by sol-gel spin coating method onto glass substrates. Zinc acetate dehydrate, 2-methoxethanol and monoethanolamine (MEA) were used as a starting materials, solvent and stabilizer respectively. The molar ratio of MEA to Zinc acetate dehydrate maintained at 1.0 and the concentration of Zinc acetate dehydrates was $0.75 \mathrm{M}$ (molarity). This mixture was mixed on hot stirrer plate at $70^{\circ} \mathrm{C}$ for $45 \mathrm{~min}$. The glass substrates were precleaned detergent, and then cleaned in methanol and acetone for 10min in ultrasonic cleaner and then cleaned with deionized water and dried in oven at $100^{\circ} \mathrm{C}$ for $15 \mathrm{~min}$. The spin coated at 300,400 and 500 r.p.m for 40sec. After deposition by spin coating the film was dried at $350^{\circ} \mathrm{C}$ for $15 \mathrm{~min}$ in furnace to evaporate the solvent and remove organic residuals (this step was repeated seven times to obtain reasonable coated layers for the $\mathrm{ZnO}$ product onto the selected substrates. Three glass substrates were prepared for each speed and the images were taken using optical microscope for qualitative first test, and then taken FTIR test for glass substrate samples Figure 1 show the flow chart showing the procedure for preparing $\mathrm{ZnO}$ thin films.

\section{RESULTS AND DISCUSSION}

There are many factors affecting the crystallization behavior of these films, such as the properties of stabilizers, like MEA, the duration and temperature of reflux, molar ratio of the starting material, the type of substrate and spin coating speed.

The sol system requires a delicate balance. Increasing the water content and dilution of the sol system and decreasing the duration of reflux may cause the sol to gel immediately. MEA and water are added to keep the sol solutions stable and clear for 60 days. The solution is refluxed until it is clear and homogeneous.

The morphology and texture of $\mathrm{ZnO}$ thin films made by the sol-gel process are affected by solvent, preheating and post heating temperatures, concentration of sol, substrate and coating procedure.

The thermodynamics of the nucleation and crystal growth of the $\mathrm{ZnO}$ thin films indicate the occurrence of a transformation from the amorphous to the crystalline state. This crystalline growth of predominately $c$-axis orientation depends on the surface energies of the film and the glass substrate and the interfacial energy between them. In the crystal growth, a 
fast growing plane generally tends to disappear leaving behind slower growing planes with lower surface energies ${ }^{(7)}$.

Figure (2) show the XRD pattern of the five-layered $\mathrm{ZnO}$ thin film on the glass substrate by spin and dip coating, Furthermore, XRD shows that the films have a glass structure with a $c$-axis that is predominantly (002) oriented, when crystallized at higher temperatures (highest at $550{ }^{\circ} \mathrm{C}$ ). The growth of $\mathrm{ZnO}$ thin films with a (002) orientation is kinetically preferred, reflecting that the highest density of $\mathrm{Zn}$ atoms is found along the (002) plane ${ }^{(2,8,9)}$. Optical transmittance of $\mathrm{ZnO}$ thin films preheated at $275^{\circ} \mathrm{C}$ for $10 \mathrm{~min}$ and post heated at $350^{\circ} \mathrm{C}$ for $1 \mathrm{~h}$.

Figure (3) show the FTIR beak for $\mathrm{ZnO}$ with high purity intensity beaks at $400 \mathrm{rpm}$ spin coating speed.

From Figure (4) show the smallest particle size with uniform distribution of $\mathrm{ZnO}$ film occur at $400 \mathrm{rpm}$ because of relation between speed and dispersion and growth time of $\mathrm{ZnO}$ micro particles ${ }^{(10,11)}$.

\section{CONCLUSIONS}

The goal of sol-gel processing is to provide micro scale control over the structure of a material from the earliest stages of processing. For pure material powders, thin films, fibers, and even monoliths this goal has been achieved ${ }^{(12)}$.

\section{REFERENCES}

1- S. Ilican, Y. Caglar, Preparation and Characterization of ZnO Thin Films Deposition By Sol-Gel Spin Coating Method, Optoelectronics and Advanced Materials, vol.10, no. 10, p. 2578-2583, 2008.

2- L. Xiao-bo, S. Hong-lie, Optical Properties of Nanosize ZnO Films By Sol-Gel Process, Transactions of Nanoferrous Metals Society of China, vol. 17, p. 814-817, 2007.

3- G. B. Williamson, Pankove, J. I. In Optical Processes in Semiconductors; EnglewoordCliffs, N., Ed.; Prentice-Hall Inc.: 2002.

4- R. Shaoqiang, Z. Jian, F. Xiao, W. Xiaohua, L.Laiqiang, S. Yanling, X.Qingsong, W. Chang, Z. Jianzhong, Z. Ziqiang, Appl. Surf. Sci. 241 (2005) 384.

5- P. U. Garcia, Synthesis and Optical Properties of $\mathrm{ZnO}$ Nanostructures with Different Morphologies, opt. Mater, 29, 65-9, 2006. 
6- A. Talbi, F. Sarry, J. Amorphous and Liquid Semiconductors,Plenum Press, New York128, 78, 2006.

7- J. J. Chen, F. Zeng, B. Demirci, J. Optoelectron. Adv. Mater. Joint Committee on Powder Diffraction Standards, Powder Diffraction File, card no: 36-1451485, 257, 2005.

8- J. Yoo, J. Lee, S. Kim, Super lattices and Microstructures in press. Thin Solid Films, 480, 213, 2005.

9- M. Caglar, Y. Minoura, A.K. Sarkar, A. Akiba, A. Kamiya, T. Endo, Thin Solid Films Advance Materials, 8, 1410, 2006.

10- G. Srinivasana, N. Gopalakrishnane, Superlattices and Microstructures in Press, 78, 564, 2006.

11- M. Hong, L. VanBhattacharya, P.; Katiyar, R. S. Mater., Journal of Alloys and Compounds, 449, 207, 2008.

12- A. Banerjee, C. C. A. J. Cryst. Growth 2005, 274, 412.Ghosh, Thin Solid Films, 496, 112, 2007. 


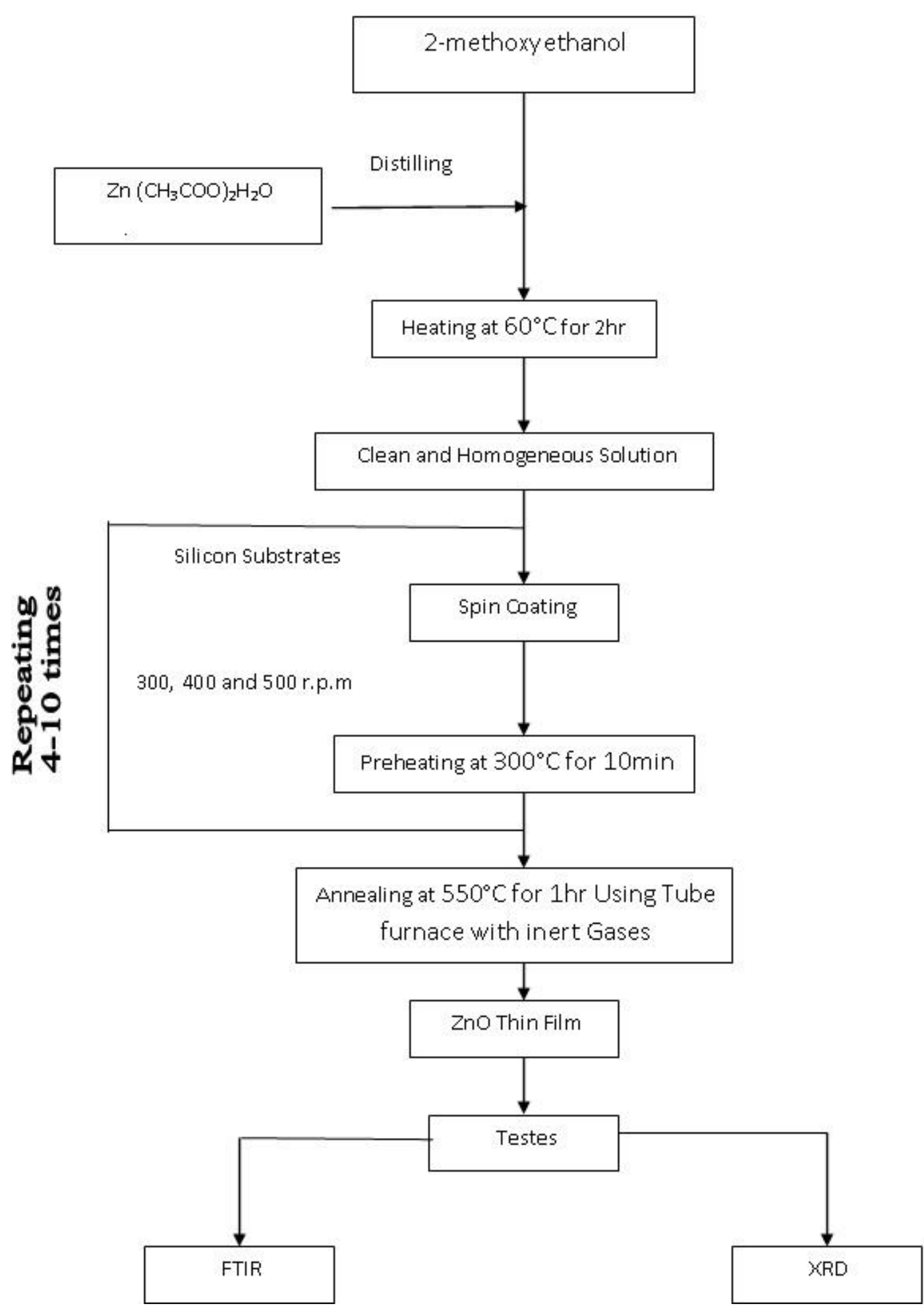

Figure (1): The flow chart showing the procedure for preparing $\mathrm{ZnO}$ thin films ${ }^{(3)}$. 


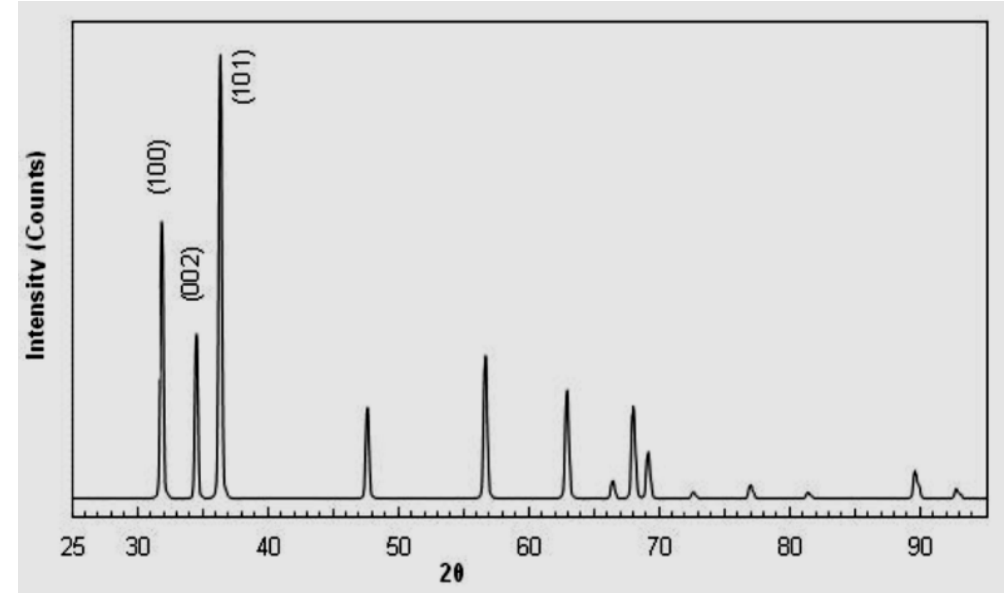

Figure (2): Show the XRD pattern of the five-layered $\mathrm{ZnO}$ thin film.

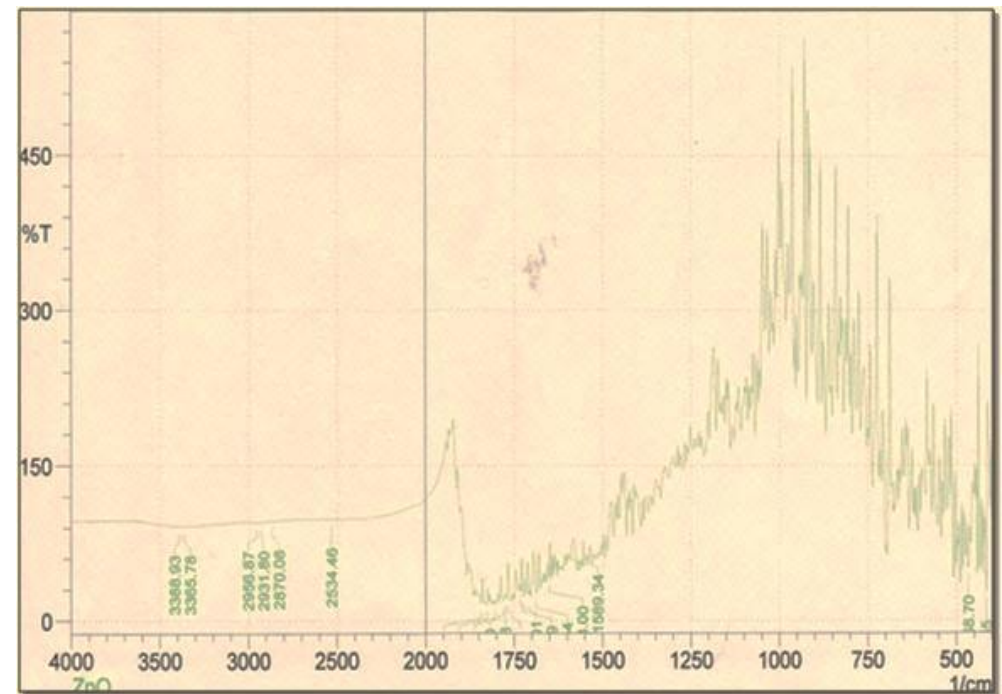

Figure (3): Show the FTIR beak for ZnO.

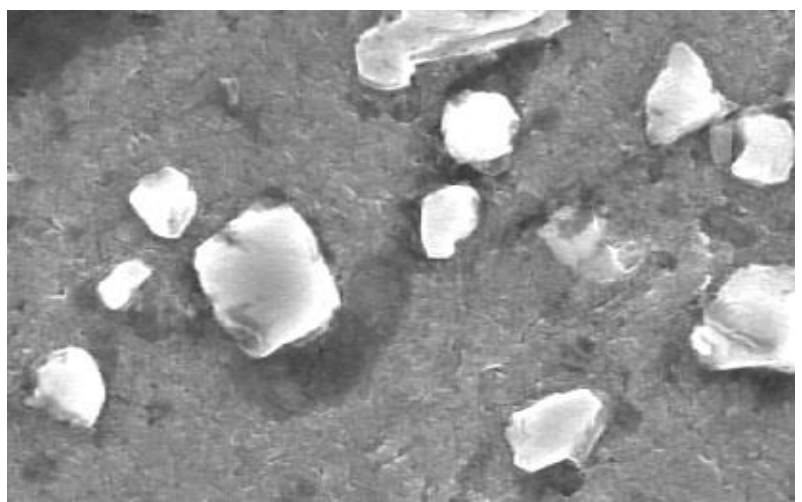

Figurer (4): Show the smallest particle size with uniform distribution of $\mathrm{ZnO}$ film occurs at $400 \mathrm{rpm}$. 
تأثير الطلاء بالدوران السريع والترسيب على الواح رقيقة من اوكسيد الزنك الراتنجي ZnO

$$
\begin{aligned}
& \text { عقيل علي ناظم 1, صفاء محمد حسوني 2, علي حسين علي } 3
\end{aligned}
$$

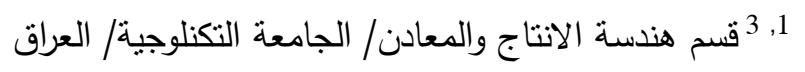

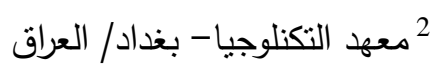

تم في هذا البحث الترسيب لمادة أوكسيد الزنك ZnO الراتتجي على ألواح زجاجية مختبرية بطريقة الطلاء

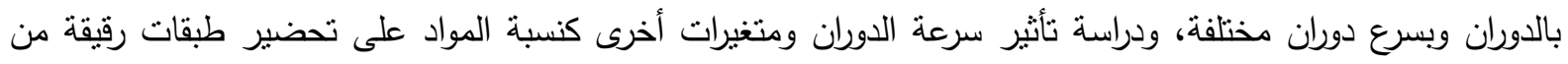
المستخدمة في صناعة أثباه الموصلات. وأجري عليها فحوصات يود الأشعة السينية وفحص مطيافية الأشعة تحت دائة الحمراء، أنه تم الحصول على أنعم حجم بلوري عند درجة حرارة تجفيف 300C وعند سرعة دوران 400 rpm. 